Journal of Teacher Education for Sustainability, vol. 19, no. 2, pp. 51-68, 2017

\title{
School-based Teacher Training in Jordan: Towards On-school Sustainable Professional Development
}

\author{
Ahmad Alkhawaldeh \\ University of Jordan, Jordan
}

\begin{abstract}
Despite the challenges to develop school-based sustainable teacher training and development and the diverse demands to execute this type of teacher professionalism to achieve sustainable teacher development, this new trend seems indispensable both for Jordanian teacher education and many other similar world educational systems. The present qualitative study robustly relied on a set of self-reports developed by 12 doctoral students who took a teacher education course at the University of Jordan in the second semester, 2017. They self-reported on their perspectives on school-based teacher training in terms of its significance, requirements, challenges and possible solutions to develop this route to teacher training in a country which like several other educational systems worldwide was dominated by an academic theory-based route to teacher preparation and qualification. Their self-reports were analysed and their patterns concerning the reasons behind adherence to school-based teacher training and the facilities to promote it and the challenges for school based teacher training were collected and meticulously probed. The findings of the study noticeably advocate school-based teacher training as a major route to teacher training. The participants of the study obviously considered this training route a method to transfer training experience to the teachers' classroom instruction. Some recommendations were proposed calling for adopting this new training approach and conducting further research in this emerging paradigm.
\end{abstract}

Keywords: teacher education, school-based teacher training, sustainable professional development

\section{Introduction}

Teacher education for sustainable development is an educational paradigm that considers life-long professional development and learning of teachers as the main hub of teaching practice. Sustainability and sustainable development have recently become widely discussed in the educational arena, in general, and in teacher education and development, in particular. For example, Salite (2015) called for the reorientation of teacher education towards sustainable development. At the heart of the debate on sustainable professional development of teachers, there is the shift from traditional one to 
more school-based teacher professional development, which the present study attempts to address. Recently, sustainable education and teacher education integration into the wider system of higher education and teacher education milieu have attracted the attention of policy makers, educationists and researchers who are willing to make these people care about issues and concepts that relate to climate change and global warming among other related global issues and concerns. Teacher education is being viewed to take the lead and consider such issues. Teachers are urged to equip themselves with new skills and high standard professional knowledge to assume new roles and responsibilities in sustainable education in their societies (Kabaday, 2016). Teacher education in the context of sustainable education should abandon conventional teaching models and shift to a transformative model of education to account for the twenty-first century humanity demands for living sustainably in a globalised world (Bell, 2016). With this new trend in teacher education, teachers are essentially required to exhibit teacher renewal and professionalism.

According to Williamson and McDiarmid (2008), the continuum of teacher learning as well as teacher education turns out to be indispensable in a lifelong learning process which implies the demand for extended teacher professionalism. This implies that teacher education and learning, which the present study is premised on, should continue through the whole teacher development and should feature all teacher experiences during career long learning.

The present study, basically, envisions a new model of teacher education and training which puts special emphasis on the school as the key site for sustainable professional development of Jordanian teachers rather than the conventional all-for-all trainees model, which according to some research, is excessively theoretical and hypothetical in nature while the recent trend gets to line up with sustainable education of teachers.

\section{Background of the Study}

As the context of this study, the educational system in Jordan, resembling several world educational systems, aims to achieve modernisation, productivity, good citizenship and social and sustained economic growth of the country. It also desires to equip Jordanian people with life-long skills and experiences by creating an educated population and well-skilled workforce. The ultimate goal of achieving teacher education goals will turn to be a reality when there is a sustainable educational system that can achieve these objectives. The vision of the educational structure in Jordan is to respond to and stimulate sustained economic growth through an educated workforce and population.

In Jordan teacher education used to be the responsibility of two-year teacher institutes. It was not until the end of the 1980s when teacher education in Jordan started to take its initial shape with the first educational reform conference held in 1987. Consequently, the 1990s witnessed the attachment of teacher education programmes as supported by a Jordanian-European project to achieve the main objective of boosting teacher education in the country. Therefore, most governmental universities in Jordan established teacher education programmes to train prospective teachers (Abu Naba'h and Abu Jaber, 2017). Around 2004, teacher education programmes at Jordanian universities were reduced to a smaller number of programmes.

The Jordanian Ministry of Education recognises that developing the quality of teacher education is the major priority for the Jordanian national development where 
the main tool to achieve this goal encompasses the development of the quality of teacher education adopting various reform policies and strategies, on the top of which there is the improvement of teacher training. Therefore, the Ministry's response took the shape of a national project 'The Education Reform for Knowledge Economy' (ERfKE) which was divided into the two main phases: ERfKE I that took place in the period of 20032009, and ERfKE II that took place in the period of 2010-2015. The main goal was to enact an educational reform to improve professional development of teachers apart from other educational goals.

Since then, calls are on rise to get the Ministry of Education to support teacher education and training recognising the role played by teacher education programmes at Jordanian universities. Recently, there have been calls for school-based teacher education for various merits perceived by the Ministry of Education to prepare prospective teachers. This is supported by dissatisfaction with the traditional platonic form of teacher education where academies were awarding degrees and qualifications to teachers who, according to several educationists and practitioners, were not sufficiently educated and trained to account for the teaching responsibilities and the changing forms of the teaching profession. Meanwhile, there were calls for establishing partnerships between teacher education programmes and projects and initiatives of the Ministry of Education to educate and train teachers, but, until now, these remained mere calls to be applied.

Teacher education in Jordan, as the case of many world counties, is in a continuing flux due to domestic and global professional development, teacher education, training changes and trends seeking sustainable teacher education and development. Due to the increasing and widespread criticism of centralised in-service teacher training where large numbers of new (prospective) teachers are brought together and taught theory, the onsite (decentralised) sustainable teacher training has come to the surface and seems to receive a popular reputation and support over the centralised route for several reasons. In consonance with these directions, UNESCO Recommendations for Reorienting Teacher Education to Address Sustainability (2013-2014) exemplified the demand for the reorientation of curricula and teacher education.

The conventional in-service training is based on holding training courses and workshops for large numbers of newly appointed school teachers. They are assumed, after finishing their in-service training, to transfer mostly theory they received from their trainers to classroom instruction. This has recently turned to be a less favoured option due to various shortcomings of this form of teacher training among which there is the discrepancy between the training input received from these programs and the school instruction and teacher demands. Therefore, there is an urgent demand for schoolbased teacher training, rather than the conventional form of in-service teacher training, which tends to get the attention of policy makers in the educational sector and gains the attention of teachers and supervisors, as well as school principals. In 2005, the Schoolbased Teacher Training Conference was held in Jordan, which attracted the attention of the Royal Committee for Education, teachers, supervisors, as well as the personnel and experts of the Ministry of Education. The conference was also supported by international agencies such as the USAID. Now, it has become popular that the schoolbased teacher training is the most possible route to teacher training though there are calls for a partnership between universities and the Ministry of Education for the preparation of potential prospective teachers, in-service teacher training and the sustainable development of teachers. Some international trends, such as in England, call for initial 
teacher training being the province and be hosted by the schools with focus on this trend over the university-led route. School-based teacher training, according to international literature, enables the trainee to influence the school environment, especially in the domain of behavioural management skills. Training at school deepens links with schools and may offer the trainee an opportunity to find a post at school after finishing the training programme. It is believed that the school-based teacher training provides a solid foundation for success in the future. Erawan (2015) did not support the used form of in-service teacher training and due to factors that have to do with the school management and direct supervision of teacher training and continuity of life-long skills, the scholar, alternatively, tended to favour the school-based teacher training route.

\section{Research on the In-service Teacher Training and the Continuing (Sustainable) Professional Development}

Various research studies have highlighted the career-long professional development and learning so as to improve teacher quality (Day, 2002; Niemi, 2015). The shortcomings of the initial teacher preparation were identified demonstrating the inadequacy of this preparation to meet the needs of teachers to develop their professional learning via their teaching careers. Until 2005, research drew attention to factors impacting teachers' work and the on-going commitment, stamina and effectiveness of teachers throughout the teachers' professional life cycles (Day \& Gu, 2007; Sammons, Mujtaba, Earl, \& Gu, 2007).

Worldwide, there is an increasing perception of the careful development of teachers professionally during the course of their professions to be effective teachers. This requires provision of support and retaining of teachers to create an effective learning environment so as to improve learning and support the work environment for teachers to develop and to keep on developing the teachers' expertise (Evers, Van der Heijden, \& Kreijns, 2016). This would mean the improvement of the whole school environment. This cannot be achieved without collaborative teachers who should demonstrate coherence with school policies, curricula, focused content and inquiry learning approaches (Badri, Alnuaimi, Mohaidat, Yang, \& Al Rashedi, 2016).

As stated above, the need for robust and systematic teacher preparation and development has gained increasing momentum. As far as the on-site- professional development is concerned, this has been found to include multiple routes to teacher development such as mentoring, peer coaching, observing teachers, modelling and providing feedback to other teachers. Practice is enhanced in an on-going process when the continuing professional development of teachers offers richer professional development experiences than is the case with short term teacher development (Kelly, 2006).

The present mainstream seems to support professional development when it goes with the school culture and when it exhibits attributes of peer-learning, cooperative and sustainable development (Darling Hammond \& Richardson, 2009). There is evidence that supports collaborative continuing professional development that aims to meet the professional development needs, while similar evidence supports that teachers need to have ownership over their professional development.

According to Mohammadi and Moradi (2017), continuous professional development is valuable for teachers in implementing sustainable education. Therefore, the exploration of the perceptions of teachers could be an important attempt since their 
beliefs influence their classroom practices, thus affecting their students' learning. The findings of their study demonstrate that beliefs about continuing professional development are subject to change. This result was also consolidated by a set of semi-structured interviews. The results also demonstrated that the participants considered professional development programmes to be useful. The study provided some pedagogical implications directed toward sustainable professional development.

Gholami and Qurbanzada (2016) found out that in-service teachers had a negative perspective towards the impractical courses which tended to be not practical in the real classroom environment and they regarded them as less powerful. The participants of the study found courses related to teaching like teaching methodology, of special sustainable nature and beneficial in the actual teaching context. Further, the participants asserted that it was necessary for the universities to integrate practical courses such as the practicum as well as classroom observations in the university curriculum to promote more genuine learning.

Kabadayi (2016) investigated pre-school teachers' needs concerning in-service training courses to put forward an effective model built up on their needs assessment to attain sustainable Turkish education. Referring to Salite (2008), she called for on-site training courses that can be like an agent for educational change by the teachers who are willing to expose themselves to the challenges and innovations of teaching.

Cordingley and Bell (2007) suggested that teachers can be supported in their sustainable professional development when there is the help from an expert. Strong evidence has found that teachers establish a starting point in their professional needs where training is tailored along with such needs. This meant that teachers with specialist expertise assumed autonomy as they progressed in their training.

A study by the OECD (2009) indicated that school leadership can play an important role in the development of other school teachers. School leaders with a strong instructional leadership may benefit from further professional development to remedy teachers' weaknesses, promote good student-teacher relations, create teacher collaboration, and encourage teachers to achieve innovative teaching strategies. According to Drago-Severson (2007), this can be achieved by offering leadership roles to teachers; ensuring teaming, collaborative inquiry as well as reflective practice and mentoring.

Buitink (2009) studied how student teachers learn how to practice teaching during the school-based teacher education programme. The study explored the changes that student teachers experienced in their practical theories and reflected on the student teachers modification of their theories. All eight student teachers were monitored during their teaching practice. The study revealed that all participants expanded their broad, well-structured practical theories, which focused on their pupils' learning strategies. However, their learning strategies exhibited substantial individual variation. Based on the study findings, the learning in a work-based context was highlighted.

Arani (2001) conducted a study that used the case study method to describe the characteristics of Japanese school-based in-service teacher training programmes, which were designed to help teachers improve their competence and the quality of their teaching activities. The data came from observations of and interviews with teachers in classrooms within 10 public elementary schools. School-based in-service teacher training is based on planning and conducting collaborative research activities. Teachers learn from each other, from their relationships with students and from enhanced professional dialogue. Japanese teachers view professional development and enhancement of their teaching 
skills as a lifelong pursuit. They know that experience, self-study, critiques of their teaching by their colleagues and self-reflection are important parts of this process. Instead of one-time workshops on the latest educational topics, they are engaged in a long-term process of self-reflection and development. The study proposed a model of improving teacher competence that consisted of four teacher improvement efforts: teachers on their own; teacher-student relationships; teacher collaboration and finally teacher-parent cooperation.

Hurd (2008) investigated the effect of teacher training on secondary student outcomes. The additional benefit schools receive from involvement in teacher training offers the school an opportunity to uplift standards, but this might influence the school students' achievement by getting students being taught by inexperienced prospective teachers and the resulting diversion of mentors' efforts from the classroom instruction. The findings of this study revealed that the number of trainees did not have any significant effect on school results. Depressing effect was left in case of low number of trainees while, on the other hand, larger numbers did not have a negative effect.

Badri, Alnuaimi, Mohaidat, Yang, Al Rashedi (2016) reported on findings from the 2013 study for Abu Dhabi that collected teachers' views on teaching and learning with a special focus on teachers' professional development. The aim was to understand teachers' perceptions regarding professional development needs and influences as well as the barriers encountered by Abu Dhabi secondary teachers. The study threw light on the variations of their views in relation to other independent variables such as teachers' age, gender and type of the school. The most prevalent variation was observed concerned public or private schools. Male teachers consistently assigned higher perceived influence scores than female teachers. Public schools, on the other hand, assigned higher influence scores for the activities which they participated in. Female teachers assigned higher barrier scores to five of the seven barriers to the participation in professional development tasks. The research recommended that the professional development programmes should ensure the effectiveness of the professional development chances for educators in Abu Dhabi educational zone.

Niemi (2008) envisioned teacher professional development as if it were a continuum which extended from pre-service education and continued through the newly qualified teachers' induction stage, and covered a career-long development. According to the scholar, Finnish teachers' work contexts provide high level of professional autonomy in their work. The role of pre-service teacher education is to prepare them for this responsibility. Previously, in-service training occurred over training days and via short training courses. The new training trend looks at teachers as developers in the school community. Teachers should design school-based projects and their development is part of the whole school development. The article reflected on new forms in which this new trend was implemented where, for example, the school supported the multi-professional cooperation in the school community. The other is to design a school community which uses a design-based approach in cooperation with many partners, and the third form implies the promotion of connection between pre-service and in-service research-based teacher education and, finally, the promotion of induction for new teachers.

Alkhawaldeh (2001) conducted a qualitative investigation on language teacher education models in Jordan. He reflected on three models that used to shape teacher education from the perspective of various stake holders including university professors, mentors, student teachers and school supervisors. The first model was the university- 
based model that asserted the role of academy in teacher preparation and academics believe that the student teachers should possess knowledge of different academic theories to practice teaching. The second model was the partnership model between academy and institutions that employ teachers as workforce in schools. This trend was believed to get all stakeholders to reach a consensus among them to agree on the standards and the theories which teachers need to practice teaching. A final model or route was the school-based one. It has recently started to attract the attention of many stakeholders that believe in the on-site or work-based teacher education where teachers are directly supervised by more capable peers who are more knowledgeable about teaching and who can transfer their experiences to those who need knowledge and experience about teaching. The present study matches with this direction as it is receiving continuing attention and can potentially achieve the sustainable professional development of prospective teachers.

\section{Statement of the Problem}

Through teaching graduate courses in curriculum and instruction, the researcher has noticed the general allegiance among graduate students who are mostly practicing teachers at Jordanian and some regional schools and universities to a kind of teacher training that is based on the school. Most of them tend to favour the on-site route to the training and preparation of teachers. The Jordanian teacher education and training was traditionally dominated by theory-based teacher education and training where either pre-service or in-service professional development was mostly built up on the premise that a new teacher was provided with knowledge about teaching and some practical application and was then supposed to translate the acquired knowledge and experience into classroom teaching practices, which, according to many stakeholders, did not fully turn into reality. Calls and projects to make teacher education more decentralised and based on the school, has recently captured the attention of policy makers, school principals and educationalists. This new trend was coupled by international calls to set the school as the centre for the teacher sustainable professional development as the school could afford training to its teachers to be less costly and more workable on condition that it could spot teacher experiences and prepare or allocate mentors of more experience and knowledge about teachers who could transfer this experience and knowledge to less experienced teachers at their schools. The present study investigates this new phenomenon in the area of teacher education in Jordan, taking into account the factors that push teacher education towards the school-based teacher education, which is expected to foster life-long sustainable professional development.

\section{Purpose and Questions of the Study}

The present study investigates the shift in perspective from theory-based teacher training to school-based sustainable teacher training as experienced by a cohort of doctoral students taking a course on teacher education at the University of Jordan. What follows is a set of research questions which the present study attempts to address.

1. What are the reasons behind favouring sustainable school-based teacher education? 
2. What qualifies the school to be the centre for school-based teacher training?

3. What are the challenges that may encounter sustainable school-based teacher training?

4. How does the school overcome the challenges to develop sustainable schoolbased teacher training?

\section{Participants of the Study}

$12 \mathrm{PhD}$ students taking teacher education course at the University of Jordan as part of their doctoral study requirements provided their opinions on the on-school teacher training. All of these doctoral students were preparing for a doctoral degree in (General) curriculum and instruction. A few of them were occupying key positions in their countries. Two of them were Yamani students, one Emirati, while the rest were Jordanian students. Most of them (11 students) were practicing teaching at various levels in their countries and seemed familiar with school-based teacher training. At present, school-based teacher training is receiving attention of educationists, teachers and policy makers.

\section{Significance of the Study}

The present study addresses the views of a cohort of (12) highly qualified school teachers. It will be more useful and valuable to several concerned people among which are those who do care about shifting teacher education to achieve school-based teacher training to attain sustainable professional development. This new trend will be more attainable if policy makers are enthusiastic and willing to reform teacher education. Schools, whether private or public, will find the outcomes of this study uniquely related to their policies as sustainable professional development. Several education directors at various educational directorates may find the results of the study highly useful as well. Finally, the researchers who search into areas of teacher education, in general and sustainable professional development of teachers' instructional performance, in particular, may benefit from the findings of this study and can also build up on these results to explore more about the possibilities of making school-based sustainable professional development a reality.

\section{Limitations of the Study}

This current study was limited to the research tool which was the self-report instrument used for the purpose of this study. It was also confined to a sample of 12 participants of doctoral students taking a course on teacher education at the University of Jordan, who reported on the new perspective of school-based teacher training. The time line of the study was also a restriction where the study was conducted during the second semester, 2017. 


\section{Research Tools}

The research tool used in the study consisted of a self-report where the participants voiced their views on the significance of school-based teacher training, the reasons behind adopting the school-based teacher training, the requirements to execute this type of training, the challenges encountered and suggestions to overcome these challenges. Five specialists in the field of teacher education from various sub-disciplines who held $\mathrm{PhD}$ degrees established the validity of the research tool. The self-reports were written at the end of the second semester, 2017. They were collected and analysed by looking for patterns in the responses of the participants of the study.

\section{Validity}

The form of self-report items was forwarded to eight university specialists in teacher education and curricula from various universities in Jordan. After reviewing the items of the self-report, all reviewers agreed on the suitability of the instrument and suggested a few points to modify it. The final version was produced taking into account the com ments and remarks of the reviewers.

\section{Reliability}

After establishing the inter-rater reliability of the self-report instrument by getting two analysts to analyse the data obtained from the reports and calculating agreement between the two analysts, the researcher looked for patterns among the responses to the research questions. The responses were tabulated to serve the purpose of this study.

\section{Data Analysis}

Data collected via the qualitative tool in the study were qualitatively analysed. First, responses to the items of the self-report were coded and intensified to allow for patterns to emerge from the mass of data. Secondly, responses were grouped according to the questions in the self-report. Thirdly, related responses were used to answer the research questions. Finally, essential quotes were selected to support and cross match with related responses.

\section{Findings}

The results of the present study set out the reasons for selecting school-based teacher training, the requirements and facilities available in the school that are likely to facilitate school-based teacher training, the challenges encountered by the execution of the schoolbased teacher training and, finally, address the issue development of school-based teacher training.

Table 1 presents the merits of school-based teacher training highlighting among these the flexibility of this kind of training, the consideration of individual teacher's needs, the qualitative improvement of the school instruction and the development of positive attitudes among teachers toward the teaching profession. School-based teacher 
training cannot be implemented without guaranteeing, for example, a school environment supporting this new route of teacher training.

Table 1

Description of Reasons for Adopting School-based Teacher Training

\begin{tabular}{|c|c|}
\hline No & Reasons for adopting school-based teacher training \\
\hline 1 & Needs of school teachers are considered following this kind of school training \\
\hline 2 & On-site training can qualitatively improve teacher's teaching performance \\
\hline 3 & $\begin{array}{l}\text { Training outside the school does not consider individual needs of teacher and the } \\
\text { school }\end{array}$ \\
\hline 4 & $\begin{array}{l}\text { On-site training can unify teacher's school related discourse and intersect with the school } \\
\text { policy and system }\end{array}$ \\
\hline 5 & $\begin{array}{l}\text { Unification above can enable the school to integrate the curriculum that can finally } \\
\text { improve the learning performance of the school students }\end{array}$ \\
\hline 6 & $\begin{array}{l}\text { Leaders should have training inside the school to enable teachers to have coherent language } \\
\text { and strategies }\end{array}$ \\
\hline 7 & ng can offer opportunities for all school teachers \\
\hline 8 & dents \\
\hline 9 & fulfillment of the needs for professional development of \\
\hline 10 & $\begin{array}{l}\text { The school can make up for any shortages in the teacher's qualificatio } \\
\text { initial teacher training and preparation }\end{array}$ \\
\hline 11 & $\begin{array}{l}\text { chers training tailored around their speciality, } \\
\text { students }\end{array}$ \\
\hline 12 & $\begin{array}{l}\text { On-site training opens the chance for collaborative discussion and debate with the trainer } \\
\text { where this can be followed up with the teacher immediately and possibly simultaneously } \\
\text { during training }\end{array}$ \\
\hline 13 & $\begin{array}{l}\text { This training enables the teacher to overcome real problems encountered in real-life } \\
\text { teaching }\end{array}$ \\
\hline 14 & Positive attitude toward teaching is developed \\
\hline 15 & Teacher's attitude toward the school at which they train is developed \\
\hline 16 & The trainee teacher has commitment toward the school where he or she \\
\hline 17 & $\begin{array}{l}\text { The trainee teacher becomes more flexible and can have self-renewal due to school- } \\
\text { based teacher training received }\end{array}$ \\
\hline 18 & This approach enables teachers to develop their teaching skills \\
\hline 19 & ling can qualitatively improve teacher's teaching pe \\
\hline
\end{tabular}

Table 2 highlights that the school principal should possess knowledge and skills to practice the role of introducing and implementing teacher training at school. It also requires that the school administration should be able to assess the skills and knowledge of school teachers to decide how to improve their teaching methods and skills. 
Table 2

Requirements for the Development of the School-based Teacher Training

\begin{tabular}{ll}
\hline No & \multicolumn{1}{c}{ Requirements for implementing school-based teacher training } \\
\hline 2 & $\begin{array}{l}\text { The school principal should possess the essential knowledge and skills that enable him } \\
\text { to play such a role. }\end{array}$ \\
\hline 3 & $\begin{array}{l}\text { The school administration should be aware of how to assess teachers' teaching perform- } \\
\text { ance and identify the weaknesses and strengths in order to develop the skills of strong } \\
\text { teachers and improve those of less-experienced teachers }\end{array}$ \\
\hline 4 & Offering incentives for teachers \\
\hline 5 & A well-resourced training environment should be guaranteed \\
\hline 6 & $\begin{array}{l}\text { The school administration can help teachers sort out any problems encountered in the } \\
\text { process of training }\end{array}$ \\
\hline 7 & The school should keep abreast of the recent instructional and training trends \\
\hline 8 & $\begin{array}{l}\text { The school principal should possess the essential knowledge and skills which enable him } \\
\text { or her to play such a role. }\end{array}$ \\
\hline 9 & $\begin{array}{l}\text { The school administration should be aware of how to assess teachers' teaching perform- } \\
\text { ance and identify the weaknesses and strengths in order to develop the skills of strong } \\
\text { teachers and improve those of less-experienced teachers }\end{array}$ \\
\hline
\end{tabular}

Table 3

Facilities that Qualify the School to Host School-based Sustainable Teacher Training

\begin{tabular}{ll}
\hline No & \multicolumn{1}{c}{ Facilities that facilitate implementation of school-based teacher training } \\
\hline 1 & Teachers' experiences and school administration's experiences \\
\hline 3 & $\begin{array}{l}\text { The school is the site where action research can be conducted directly and where } \\
\text { application of recommendations is possible }\end{array}$ \\
\hline 4 & $\begin{array}{l}\text { The school is the site where training quality can be directly judged and compared among } \\
\text { several teachers' experiences }\end{array}$ \\
\hline 5 & $\begin{array}{l}\text { The school is the place where school facilities can be benefitted from } \\
\text { skills }\end{array}$ \\
\hline
\end{tabular}

As the school is the site where teacher training should take place and action research is conducted, school facilities are, therefore, benefitted from. The school is therefore more able to explore and determine the training teachers should have.

School-based sustainable teacher training is likely to face several challenges that may make its implementation difficult as outlined in Table 4.

According to Table 4, several challenges face the implementation of school-based teacher training such as lack of qualifications of some school principals and teachers, teacher overload of teaching and administrative responsibilities, lack of sufficient knowledge among some school teachers about recent theories and methods of teaching, insufficient co-operation among some school teachers to transfer their experiences and knowledge to less-experienced teachers, lack of knowledge about the vision of the schoolbased teacher training and the lack of sufficient incentives for experienced teachers to act as mentors of less-experienced teachers. 
Table 4

Challenges Encountered in the Adoption of the School-based Sustainable Teacher Training

No Challenges to school-based sustainable professional development of teachers

1 Lack of sufficient teacher experiences due to promotion or transfer from school to school

2 Overload of teaching responsibilities among teachers that forces them to cover the instructional material

$3 \quad$ Classroom size and over-crowdedness that take most of the time of teachers

$4 \quad$ Disinterest among several teachers to attend training courses or considering them routine work without any benefit therefore training focuses on the theoretical side and ignores practical training

5 Teachers' beliefs about their significant selection of the teaching profession may be a challenge in their quest for further professional development

6 Lack of support from the local community to have on-site teacher training

$7 \quad$ Not all schools have a vision about the outcomes of school-based teacher training

8 Satisfaction among some schools with the minimum level of teacher's skills to practice teaching

9 Lack of experienced teachers and supervisors to improve other teachers' levels

10 Teachers overloaded with the work of the school and scarcity of time to mentor other colleagues

11 Lack of educational leaders in schools to lead school-based sustainable teacher training

12 Some school administrations are not qualified and knowledgeable of the new educational developments in the field of teacher training

13 Lack of co-operation among some colleagues to transfer their experience to less-experienced teachers via school-based sustainable teacher professional development

14 Insufficiency of the basic initial teacher training during pre-service teacher education where some teachers do not take any educational courses during studies at the university

15 Lack of sufficient teacher experience due to promotion from one position to another or transfer from school to school

Finally a set of suggestions are proposed by the participants of the present study to improve school-based teacher training.

Table 5

Proposals to Develop School-based Sustainable Professional Development of Teachers No Suggestions to develop school-based sustainable teacher training

1 Assessing teachers' actual needs to reach a professional model that fits their actual development

2 Linking teacher's promotion with the training received that is likely to develop the training culture among teachers

3 The school and the local community should support teachers to receive on-site teacher training to become creative in their teaching

$4 \quad$ The trainer should be acceptable by the trainees and also should be flexible as well as cooperative and applicable

$5 \quad$ The school teachers should keep up with the most recent developments in their speciality and methods of teaching 
School-based teacher training should be based on the actual needs of school teachers, receive support from different stakeholders, develop trainer - trainee relationship as well as school teachers should update their teaching methods and strategies.

Further Qualitative Evidence from the Self-reports Supportive of the Sustainable Schoolbased Teacher Professional Development

Highlighting school-based teacher training and in defence of this new trend in teacher education and training, one participant said:

When the school adopts school based training, it can offer equal opportunities for all teachers in training. When the training is inside the school, the school administration is able to follow up the effect of the training on the school students' final achievement and it can detect any problems because it knows teachers' conditions and, conversely, it cannot detect these potential problems and solve them.

The other participant reflected on what the school administration should know in order to be able to assess the needs of the teachers:

The school administration should be knowledgeable of how to assess teachers' teaching performance and identify the weaknesses and strengths in order to develop the skills of the strong teachers and improve those of less-experienced teachers.

The third participant described the contribution by experienced teachers to enact a profound change in the prospective teacher's experience:

This training is significant as there are experienced teachers in the field of teaching who can transfer their experiences and knowledge about teaching to those who are newly appointed at the school. The new teacher cannot wait for so long until the central authority of the Ministry of Education holds training for new teachers where a well-resourced colleague at the school can do the job and provide skills and experiences derived from the context where the new teacher can apply.

A commitment to the school and being a model to their teachers is what one participant envisioned as the nature of the sustainable development of the school.

This school-based teacher training nurtures in the trainee some commitment to the school in which he or she receives training and becomes a model where he or she receives the attention of the school administration and school staff.

Through the adoption of this training trend that is based on the school, the school will be more able to assess the training needs of its teachers, which when collected can help uplifting the instructional performance of school teachers.

Some challenges that were perceived to impede the development of the schoolbased teacher training were best described by one participant:

Among the most recurrent challenges is that this kind of school-based teacher training is costly, and also the absence of supervisory practices where until 
now there is no governmental supervision and the lack of commitment by some teachers to the training regulations and lack of incentivizing teachers for their efforts and the idleness of some teachers to develop and engage themselves in sustainable development.

Finally, qualities of a good trainer were described by one of the participants:

The trainer should be competent in the training undertaken by him, should possess the skills that qualify bim to influence the trainee, and the trainer should leave an effect on the trainee even after the training programme. The trainer should be flexible and create a dialogic type of training with the trainees, as well as should enable trainees to apply their skills and should be interpersonally acceptable by them.

\section{Discussion}

In line with international literature and local and global trends, the present study adopts a sustainable professional development quest based on the school for many profits and strengths mentioned by the participants of this study. This inquiry has raised several school-based teacher training issues: for example, the study unfolded the issue that some trainees do not receive sufficient pre-service teacher training during their studies at the university. The study, in the eyes of the participants, has praised schoolbased teacher training for several reasons mentioned above, i.e., the teacher who receives training at school can be more loyal to its vision and message, therefore, can grow naturally. The teachers at the school can collaboratively transfer their experiences and exchange them among each other. The unification of the school vision, strategy and discourse can also be achieved if the school adopts such a type of school-based teacher training. The school trainers can also help develop the school leaders to improve their teaching strategies and can also prepare school teachers to act as mentors of their lessexperienced peers. The trainee teacher becomes more flexible and can exhibit self-renewal due to the school-based teacher training because of the received feedback on teacher performance which is provided on the spot and under the direct supervision of the mentors prepared at school. Highlighting the new trend of teacher education, Williamson and McDiarmid (2008) promoted the continuum of teacher learning as well as teacher education as fundamental in a lifelong learning process that implies the demand for extended teacher growth and professionalism. Likewise, Erawan (2015) called for adopting school-based teacher training. For example, Santone, Saunders and Seguin (2014) also reflected on new sustainable teacher education and development.

Further, this school-based teacher training, from the perspective of the participants of this study, can enable the teacher to be more flexible in the work and have a sort of commitment and adherence to the school policy and regulations. Moreover, the teacher who receives school-based teacher training can assume self-development as the needs of individual teachers can be identified, investigated and profiled. This new trend highlighted by the study is also in agreement with what other researchers have advocated (Day \& Gu, 2007; Sammons, Mujtaba, Earl, \& Gu, 2007) who called for collaborative debate to be ensued among school teachers where a constructive dialogue could be developed so that teachers were engaged in this dialogue all the time which could not be ensured by traditional teacher training. Equal opportunities are guaranteed for all the teachers 
in the school and the communication between administration and school teachers becomes easy and possible.

The reason why the school is the best to conduct school-based teacher training is that, first of all, the school can have various teacher experiences, especially large schools that employ many teachers. The school where training is undertaken can provide an ideal environment where the effect of the training can be easily followed up and measured in the actual classrooms. The school can also explore the teachers' shortages for training and qualification and so can work on the development of the teachers' teaching skills. Alkhawaldeh and Qualter (2004) suggested that school-based teacher training could possibly be considered one of the main routes to teacher training and professionalism. They reaffirmed that due to the direct co-operation and communication with experienced peers at school, new or prospective teachers could have a first-hand experience in teaching.

However, this kind of training, from the point of view of the participants, may be obstructed by factors such as the lack of experienced teachers at school where collegial development is limited or even not possible. Teachers are overloaded with work responsibilities and may not have time to get training. Some of the school administrators and teachers are not knowledgeable and lack leadership skills. Some teachers may have negative attitude toward their selection of the teaching profession and this may impede their involvement in the training process. Furthermore, the mentoring relationship may also be challenged as some school teachers may not be willing enough to transfer their experiences to less-experienced teachers. Some or most of these challenges can be sorted out if the Ministry of Education and universities have more faith in this route of teacher training.

The school-based teacher training, in the context of the current investigation, is challenged by the lack of sufficient initial teacher education by some teachers which other teachers might have therefore, this creates a situation where multi-level teacher training should be provided. Niemi (2008) highlighted continuing professional development of teachers.

Finally, the trainer who is expected to execute training should be acceptable by the trainees, knowledgeable, understandable, and should have dialogic and flexible character. This illustrates the contribution of the mentor who, in the context of this study, should be a specialist teacher at school and provide less-experienced teachers with professional knowledge and experience. Cordingley et al. (2007) suggested that teachers can be supported in their continuing professional development when help was provided by an expert.

\section{Conclusions and Recommendations}

The current study has probed the reasons behind selecting school-based teacher education and development. It has solicited the opinions of the participants via a selfreport developed by them about a set of various aspects related to a school-based sustainable teacher development route. The participants highly defended this new route and saw it beneficial, essential and contributory to teacher sustainable professional development despite various challenges encountered in its execution. Participants saw this new trend considerable of individual teacher's teaching needs and suitable to transfer experiences among school teachers at the one school and a cross similar schools with the same resources and teacher qualifications. 
On the basis of the results of the study, the author recommends wide school-based teacher development, offering opportunities to train mentors and school principals to apply this new approach and foster collaborative sustainable professional development of teachers in order to allow teachers to transfer experiences and professional knowledge to other teachers who may desperately need such a special assistance to better attain effective professional development that is expected to better contribute to the country's development in the spheres of education, in general, and teacher education, in particular.

\section{Emerging model reinforced and consolidated by the study results}

The potential model that is substantiated by the results of the present study is the school-based sustainable professional development model which should be crystallised and developed in further research. Further, the study suggests that on-site school training can create a paradigm shift in teacher education where school can lead this training through preparing mentors who are trustworthy to train less experienced teachers in their respective schools. With the school resources and accumulated knowledge and experience, potential teachers can be trained and their sustainable professional development will be sustained under more capable peers. Capable peers can, for example, select and explore the beliefs and convictions of less experienced teachers and can pick out the professional knowledge these teachers may need and can, at the same time, monitor their development route. Further, this can be achieved when the school allocates and administers training courses and workshops to implement this sustainable development. One final recommendation is to minimise all-for-all in-service teacher training and to enact reorientation of teacher education to be more of sustainable school-based teacher training. Academies can also have their share once they change from a traditional theoretical route of teacher education and training to this new model of teacher education and training. In line with global teacher education and training trends, the Ministry of Education in Jordan has started to put special faith in this constantly evolving route of teacher professionalism for the above mentioned merits though this is still a demanding route.

\section{References}

Abu Naba'h, A., \& Abu Jaber, M. (2017). Reshaping teacher education programs in Jordan. Retreived September 3, 2017, from www.memberleap.com/ icet/docs/01Abu_Nabah2c_et_al.doc

Alkhawaldeh, A., \& Qualter, A. (2004). Initial teacher training: Who should lead? University or school? Educational Journal, 18(72), 4-17.

About INS. (2017). About INSTEP. Retrieved May 4, 2017, from http://web.edu. hku.hk/ community/instep

Arani, M., \& Sarkar, R. (2001). School-based in-service teacher training in Japan: Perspectives on teachers' professional development. ERIC Number: ED456109.

Badri, M., Alnuaimi, A., Mohaidat, J., Yang, G., \& Al Rashedi, A. (2016). Perception of teachers' professional development needs, impacts $\&$ barriers: The Abu Dhabi Case. Retrieved May 15, 2017, from http://journals.sagepub.com/doi/full/10.1177/ 2158244016662901

Buitink, J. (2009). What and how do student teachers learn during school-based teacher education. Teaching and Teacher Education, 25(1), 118-127. 
Darling-Hammond, L., \& Richardson, N. (2009). Research review/teacher learning: What matters. Educational Leadership, 66(5), 3-46.

Day, C. (2002). Schools as learning communities: Building capacity through network learning. Education, 30(3), 19-22.

Day, C., \& Gu, Q. (2007). Variations in the conditions for teachers' professional learning and development: Sustaining commitment and effectiveness over a career. Oxford Review of Education, 33(4), 423-443. doi: 10.1080/0305498070 1450746

Cordingley, P., \& Bell, M. (2007). Transferring learning and taking innovation to scale. Retrieved from http:/www.curee-paccts.com/resources/ publications/transferringlearning-and-taking-innovation-scale

Erawan, P. (2015). Teacher training through school-based program in participatory learning Promotion. Procedia - Social and Behavioral Sciences, 177, 162-168.

Gholami, J., \& Qurbanzada, I. (2016). Key stakeholders Attitudes towards teacher education programs in TEFL: A case study of Farhangian University in Iran. Journal of Teacher Education for Sustainability, 18(2), 5-20.

Hurd, S. (2008). Does school-based initial teacher training affect secondary school performance? British Educational Research Journal, 34(1) 19-36.

Evers, A., Van der Heijden B., \& Kreijns K. (2016). Organizational and task factors influencing teachers' professional development at work. European Journal of Training and Development, 40, 36-55.

Kabadayi, A. (2016). A suggested in-service training model based on Turkish preschool Teachers' conceptions for sustainable development. Journal of Teacher Education for Sustainability, 18(1), 5-15.

Kelly, P. (2006). What is teacher learning? A socio-cultural perspective. Oxford Review of Education, 32, 505-519.

Mohammadi, M., \& Moradi, K. (2017). Exploring change in EFL teachers' perceptions of professional development. Journal of Teacher Education for Sustainability, 19(1), 22-42.

Niemi, H. (2015). Teacher professional development in Finland: Towards a more holistic approach. Psychology, Society, \& Education, 7(3), 279-294.

OECD Annual Report (2009). Retrieved July 18, 2016, from https://www.oecd.org/ newsroom/43125523.pdf

Salite, I. (2008). Educational action research for sustainability: Constructing a vision for the future in teacher education. Journal of Teacher Education for Sustainability, $10,5-17$.

Salite, I. (2015). Searching for sustainability in teacher education and educational research: Experiences from the Baltic and Black Sea Circle Consortium for educational research. Journal of Teacher Education for Sustainability, 6(1), 21-30.

Sammons, P., Mujtaba, T., Earl, L., \& Gu, Q. (2007) Participation in networked learning community programmes and standards of pupil achievement: Does it make a difference? School Leadership and Management, 27(3), 213-238.

Santone, S., Saunders, S., \& Seguin, C. (2014). Essential elements of sustainability in teacher education. Journal of Sustainability Education, 6, 1-15.

UNESCO. (2005). (Guidelines and Recommendations for Reorienting Teacher Education to Address Sustainability 2005-2014) Retrieved May 20, 2017, from http://unesdoc.unesco.org/images/0014/001433/143370E.pdf on 20-5-2017. 
UNESCO. (2010). (World Data on Education) Retrieved September 4, 2017, from http://www.ibe.unesco.org/fileadmin/user_upload/Publications/WDE/2010/pdfversions/Jordan.pdf.

Williamson McDiarmid, G., \& Clevenger-Bright, M. (2008). Rethinking Teacher Capacity. In M. Cochran Smith, Feiman-Nemser, S. \& D. Mc Intyre, D. (Eds.), Handbook of Research on Teacher Education. Enduring questions in changing contexts. New York/Abingdon: Routledge/Taylor \& Francis.

Why you should choose. (2017). Why you should choose a school-based route for teacher training. Retrieved May 4, 2017, from http://www.educateteachertraining.co.uk/ choose-school-based-route-teacher-training/

Correspondence concerning this paper should be addressed to Ahmad Alkhawaldeh, Prof., The university of Jordan, Faculty of educational sciences, Department of curriculum and instruction, Queen Rania str. Amman, Jordan. Email: alkhawaldeh2013@gmail.com 